\title{
The return of sociology in Danish socio-legal studies: a survey of recent trends
}

\author{
Ole Hammerslev" and Mikael Rask Madsen ${ }^{\dagger}$
}

\begin{abstract}
This paper surveys recent trends in the development of the sociology of law in Denmark. The overall argument of the paper is that, currently, the sociology of law in Denmark is marked by a striking sociological and more specifically institutional and empirical turn. This new direction in scholarship suggests not only a renewed research focus on the institutional dimensions of law but it also - and very differently from work from the I 980 os and I 990 - suggests a re-orientation towards sociology more generally. A clear consequence of this return to the sociological core of the sociology of law has been an empirical orientation towards how law is practised, how legal institutions work and, as part of that, how the legal profession takes part in both legal change and transformations of state and society. This new research relies not only on general sociological theory and method but also on the more specific elite sociology, sociology of professions and sociology of knowledge.
\end{abstract}

\section{Introduction}

This paper surveys recent trends in the development of the sociology of law in Denmark. The overall argument of the paper is that, currently, Danish sociology of law is marked by a striking sociological and more specifically institutional and empirical turn. In this way, contemporary sociology of law in Denmark differs significantly from how the sociology of law (broadly speaking) has been practised over the last couple of decades, being here either oriented towards legal theory and mainly having a legal audience in its debates on the concept of law and pluralism and polycentricity (notably Petersen and Zahle, 1995), or towards the humanities in debates on ethics, judgement and other issues of moral philosophy as well as aesthetic expression. This new direction in scholarship suggests not only a renewed research focus on the institutional dimensions of law but it also - and very differently from work from the I98os and I990s - a reorientation towards sociology more generally. If various forms of post-modern relativism marked the pluralist debate and particularly its methodology - in some cases implying a flat rejection of conventional sociological methodology - the current scholarship very firmly deploys contemporary research methods and theory from sociology to conduct comprehensive empirical studies. In important ways, the sociology of law has thereby, paradoxical as it might sound, been re-sociologicised. A clear consequence of this return to the sociological core of the sociology of law has been an empirical orientation towards how law and its institutions are practised and, as part of that, how the legal profession takes part in both legal change and transformations of the state and society. ${ }^{\mathrm{I}}$ This new research relies not only on

* Professor Ole Hammerslev, University of Southern Denmark, Department of Law. Email: ohv@sam.sdu.dk

† Professor Mikael Rask Madsen, University of Copenhagen, iCourts-Centre of Excellence for International Courts. Email: mikael.madsen@jur.ku.dk.

Madsen's research is funded by the Danish National Research Foundation Grant no. DNRFio5.

I Some have even argued that this renewed focus on law and legal institutions 'in action' marks the emergence of a neo-Scandinavian realism; see Holtermann (2013) and Madsen and Olsen (20II). 
general sociological theory and methodology but also on more specific elite sociology, sociology of professions and sociology of knowledge.

In fact, with few exceptions, current scholarship in Danish sociology of law has more in common with the Scandinavian pioneers of the discipline than the generation immediately preceding them. As we will outline below, many of the first generation of scholars of the sociology of law were heavily influenced by then-contemporary sociology. The perhaps most striking example of this is the work of Vilhelm Aubert, who studied at both Berkeley and Columbia and transformed himself from being a lawyer to becoming the pioneer of sociology in his home country, Norway. In his seminal work there is a notable influence first from Talcott Parsons's functionalism and later from the Chicago School and symbolic interactionism. Contemporary Danish sociology of law exhibits a somewhat similar cosmopolitanism at the theoretical and methodological level, although the geographical orientation is now increasingly European, and particularly French. Authors such as Michel Foucault, Pierre Bourdieu and Bruno Latour are featured centrally in this new scholarship. It is precisely in this combination of a renewed centrality of sociological theory with extensive empirical studies that current scholarship takes its new direction.

This paper proceeds as follows. In Part II we provide an overview of the relatively convergent development of the discipline of the sociology of law in Scandinavia (limited to Norway, Sweden and Denmark) since World War II. First, we briefly outline the genesis of the discipline in the twentieth century and highlight some main trends in scholarship, including work on the welfare state, studies of the legal profession and alternative dispute resolution, so-called 'action research' and finally the legal and theoretical - if not post-modernist and relativist - turn of the r 980 s and I990s. In Part III, survey the survey recent studies in the sociology of law in Denmark that are representative of what we term the 'empirical and institutional turn'. Although we start with an outlining of Scandinavian sociology of law in general, our main focus in the later sections of the paper is on Danish scholarship (and particularly scholarship published in Danish), not only in order to allow for presenting the relevant studies in some detail, but also because there are to an increasing extent differences between the Scandinavian countries as concerns theoretical and methodological standpoints and research objects. We will start by outlining studies that have analysed the legal profession from a more global perspective and then focus our attention on a set of studies concerning contemporary legal institutions and their consequences. In Part IV, we draw up our findings and briefly examine the causes and consequences of the identified trends in the sociology of law more generally.

\section{The sociology of law in Scandinavia: elements of a history}

In what follows, we will outline selected elements of the history of the sociology of law in Scandinavia by highlighting a series of studies which have generally impacted the evolution of the discipline and marked its research directions. ${ }^{2}$ To shed light on this, we will first discuss a number of antecedents to the sociology of law in the region and next look into some key areas of research in the field, including studies of the legal profession, dispute resolution, action research and post-modern studies.

\subsection{The genesis of the sociology of law in Scandinavia}

One of the first attempts to write a comprehensive sociology of law in Scandinavia was made in the I 940 s by the German immigrant Theodor Geiger (I89I-I952), who, due to his involvement with the German social democrats, escaped Nazi Germany and went on to become the first professor of

2 For the history of the first sporadic attempts to develop a sociology of law, see Hydén (20I3). For the history of Scandinavian sociology of law, see also Eckhoff (I968); Hammerslev (2007a); Blegvad (I966); Ferrari (I990). 
sociology at Aarhus University. When he was forced to flee to Sweden in 1943 due to the worsening of the Nazi occupation of Denmark, he established contact with the Uppsala School of legal realism (Agersnap, 2000). In 1947 he published his seminal work on the sociology of law, Vorstudien zu einer Soziologie des Rechts (Geiger, I947), in which he presents a theoretical foundation for the sociology of law that, in line with the attempts of Scandinavian realism (Ross, I966) and legal positivism in general, tried to differentiate itself from metaphysical assumptions. ${ }^{3}$ One of Geiger's key interests was the foundational question of sociology, namely how modern society was possible at all. The legal order, he claimed, played a particularly important role in this regard. He defined a legal order as an order with a relatively institutionalised division of power (Geiger, I947, pp. I4gf.). However, although he sought to engage his sociology of law with the legal realist milieu evolving at Uppsala (the so-called 'Uppsala School'), regardless of their underlying epistemological similarities these two new progressive approaches to law never found a common ground (Geiger, I946; Ross, I950; Holtermann, Christensen and Madsen, 2013a).4

Probably more significant for the overall development of the discipline were the studies of Verner Goldschmidt (I9I6-I982) and particularly Agnete Weis Bentzon (I9I8-2013). In the late I940s, they examined informal norms in Greenland with the purpose of modernising the legal system in the then-Danish colony (Goldschmidt, Lindegaard and Bentzon, I950).5 Using anthropological methods to map existing informal norms, they studied the factors determining judgements of the official decision-making authorities in Greenland, and found that social pressure and local cultures - which were not always in accordance with the imported Danish regulation - had a real impact on local decision-makers. As a result of their study, several changes in Greenlandic law were implemented. Of these, the changes to the Greenlandic criminal code of 1954 were the most significant, not least on account of how they introduced sanctions that focused on rehabilitation, education and therapeutic help as a supplement to traditional punishment, thus focusing on an individual treatment of the criminal. Moreover, the code also handed over the discretion of sentencing to the courts. With its restorative forms of justice, the new criminal code was tailored to a society dependent on strong social ties.

Another example of an early study in the sociology of law that had a real impact was the study conducted by the Norwegian sociologist Vilhelm Aubert (I922-I988) and his associates Torstein Eckhoff and Knut Sveri of the Norwegian Housemaids' Act (I948), a law put in place to improve the working and social conditions of maids in Norway (Aubert, Eckhoff and Sveri, 1952). The relationship between housewives as employers and maids as employees in Norway had been characterised by a freedom of contract, but the Housemaids' Act implemented rules that sought to protect the maids as the more vulnerable part of the contractual relationship. Aubert et al. concluded, however, that the new Act had very limited effect. Although the Act dictated that the maids were only allowed to work ten hours per day, that there must be a written agreement between the parties and that work overtime was to be compensated - as well as a set of other clauses that protected the maids - in practice, significant changes did not occur as a result of the Act. Six years later a new study was conducted with the goal of examining whether the Act was now more widely known and implemented. While the authors reached the conclusion that no significant changes had occurred, they did detect, as the communication of the law had changed, a greater conformity between knowing the law and respecting the law. Now, more people knew of

3 Together with Torgny Segerstedt, Geiger edited Scandinavian Studies in Sociology, and was one of the founders of the International Sociological Association in I949 (Hydén, 2013, p. I03).

4 The differences between law as researched at the Faculty of Law, University of Copenhagen sensu stricto and social scientific understandings of law are to this day a major source of friction; see, for example, the recent debate (Blume, 2013; Holtermann et al., 2013b). 
the Act; however, they did so mostly from word-of-mouth and acquaintances rather than mass media or formal governmental channels.

These early studies paved the way for a nascent Scandinavian sociology of law which increasingly oriented itself towards answering the many new questions raised by the great expansion of the Scandinavian welfare states taking place in the post-war period. Generally, the growth of the welfare state implied a significant increase in the areas of social life that were regulated - for example, by social law, environment law, energy law or labour law ${ }^{6}$ - as well as a significant growth in personnel needed to administer regulations, notably jurists. As the Scandinavian model emerged with the expansive idea that the state was to take care of its citizens from the cradle to the grave in combination with income redistribution, it brought with it a massive regulation of social life. Gradually, Scandinavian sociology of law began to focus on the functions of law and regulations to improve the welfare state and, more specifically, to examine the effects of legal norms on social behaviour, particularly concerning why some norms did not perform as planned. As was the case with the early field studies in Greenland, Scandinavian sociology of law was generally interested in the role and function of law and the fundamental legal institutions in society. Most early studies were deeply empirical, aiming at the practical implications of law in order to evaluate and reform the legislative framework. This triggered a number of applied studies attempting to improve law's efficiency in the overall welfare framework. Since socio-legal activities in the region developed using broader international theoretical and methodological frameworks, the Scandinavian sociology of law of the period was characterised by the focus on the specifically Scandinavian societal model in concrete empirical studies. The relative success of the first generation of socio-legal scholars also had the important effect of the discipline being gradually institutionalised by the establishment of socio-legal departments at Lund University in Sweden in 1972 and the University of Oslo in Norway in I96I.

\subsection{Studies of the legal profession and the welfare state}

It was also Aubert who laid the foundation for another major area of socio-legal research, namely studies of the legal profession in relation to the development of the modern Scandinavian states, and particularly the transformations caused by the emergence of the welfare state (for an overview of Scandinavian studies of the legal profession, see Hammerslev, 2010, 2003). Aubert found that the legal profession was the most central profession in the nineteenth century, occupying most of the key positions in the Norwegian state, including the cabinet, the civil services, and the Norwegian parliament. Moreover, jurists held other important positions in society, not least in industry, commerce and infrastructure. According to Aubert, jurists were generalists, and legal education was a platform from which to learn the skills necessary to run society (Aubert, 1976). These observations led Aubert to the conclusion that jurists, the legal view of society and the legal model of dispute resolution played a decisive role in the formation of state and society in the nineteenth century. Having a 'nationally integrating function' due to the trust it mediated, the legal profession was, according to Aubert, a 'decisive precondition' for the development of economic growth and for the development of the modern state.

Against the backdrop of his analysis of the nineteenth century as the golden age of the legal profession, Aubert observes two countervailing tendencies in the twentieth century, namely that the importance of law had increased and, simultaneously, lost its previous significance. Concerning the first development, the number of jurists being educated had increased significantly, both numerically and in relation to the population. Moreover, legislation had also

6 Or, with Habermas, a juridification has taken place as a result of both an increase in legislation and a deepening of legal rules (Habermas, I987). 
increased significantly and many private organisations had begun to adopt legal or quasi-legal methods. Finally, another indicator of the increased importance of law was the number of criminal cases, which almost doubled from I870 to 1965. Pointing towards a decline in the significance of law, however, Aubert found that jurists in general formed a decreasing proportion of the total number of professionals. Furthermore, judges especially formed a decreasing proportion of both the population and the legal profession as a whole. If the courts were seen as expert institutions that had a service to offer, namely peaceful conflict resolution, this relative decline was remarkable, given that the number of other service professions had increased relatively more in the same period. Additionally, the number of cases that went to court had only grown modestly, and the majority of cases were settled without the aid of the judiciary; many conflicts were settled in institutions in which traditional legal methods were losing their dominance. Aubert concluded that it was difficult to explain that modern society needed courts and the legal profession more than pre-modern society did. But he found it unlikely that modern society should have experienced a decrease in the number of conflicts, which meant that the manner of solving conflicts must have changed. In conclusion, Aubert argued that the traditional legal method was losing its dominance to other forms of professional expertise. Basically, other professional groups were entering the traditional domains of jurists, which forced jurists to adjust their knowledge profile if they were to remain key players in society.

At around the same time, Britt-Mari Blegvad examined the role of the legal profession in Danish society. Employing statistics comparable to Aubert's, Blegvad argued that the number of members of a given profession indicated the total need for that specific expert knowledge in society. Yet, according to Blegvad, it is not adequate merely to discuss variations in needs in society for one single professional group; rather, the discussion must be related to other professional groups (Blegvad, I975, I973). Similarly to Aubert's analysis, Blegvad concluded that the legal profession was indispensable to the development of the modern state, yet the welfare state project implicated the growth of competing expertise, which in some cases replaced jurists as the key providers of state expertise.

A third wave of studies on the legal profession was carried out by Swedish sociologist Margareta Bertilsson in the late I980s and throughout the I990s (Bertilsson, I 996; see also Bertilsson, I989, I999, I995). In her 1995 book Law in Transformation [our translation], she took Aubert's replacement thesis of the legal profession as a starting point for also examining the place of jurists in the changing welfare state. As was the case in Norway and Denmark, in Sweden the legal profession had played a central role in the development of the modern state. Law had not only been important to the processes Aubert points to, but had also more generally been an instrument for social change (Bertilsson, I995, pp. I56f.). However, other competing professionals - mostly from the social sciences and especially after the I960s - proliferated, forcing jurists' expertise to increasingly rely on other forms of scientific knowledge (pp. 24ff.). In other words, after the middle of the twentieth century, the decision-making processes started involving other considerations and modes of knowledge than the traditional legal one. Although jurists were considered the 'midwives' of the modern state and capitalist market, it seemed as if the development of the welfare state broke the legal profession's monopoly over the law. While jurists, especially judges, became 'marginalised' in this process, lawyers were also conquering new markets internationally.

While many of these studies of the legal profession in Scandinavia revolve around some of the same theses, Bertilsson et al. end up considerably refining Aubert's 'replacement thesis'. According to Bertilsson et al., jurists have both strengthened and weakened their powerful position in society. They have strengthened their power by maintaining and even increasing their professional knowledge by specialising and differentiating themselves and by strengthening their control over legal technical questions, that is, by becoming even more technocratic. On the other hand, they 
have delimited their social status, and authority and power have decreased as they have changed their career patterns and institutional places of influence.

\subsection{Dispute resolution and action research}

Another path of research closely related to studies of the legal profession has examined the changing profile and role of dispute resolution, namely what is broadly known as 'alternative dispute resolution'. Once again, Aubert was a pioneer. In his work on dispute resolution, he distinguishes between traditional dispute resolution in court and other forms of dispute resolution such as mediation. The purpose of dispute resolution in court is to 'advance predictability by determining which facts lead to which legal consequences' (Aubert, I982, p. II2). Yet traditional dispute resolution in court also has negative consequences, as legal counselling, where one of the parties will win the case and the other will lose, can draw the parties apart. In contrast, mediation is a form of dispute resolution that seeks consensus between the parties, and all involved parties take part in solving the conflict with arguments. As such, in the latter form of dispute resolution, other forms of expertise than the traditional legal are required.

Aubert's successor, Thomas Mathiesen, also inquired into dispute resolution by conducting micro-sociological studies of the parties in trials. He observed that the main actors in a trial were the professionals taking part in the case and not the actual person on trial. The lawyers and judges communicated in a legal language without taking notice of the person on trial (Mathiesen, I 989). One of his colleagues, Nils Christie, was also interested in dispute resolution, and raised the fundamental question of who conflicts actually belong to. In a traditional dispute resolution in court, the legal professionals, so to say, 'steal the conflicts' - if viewed as an individual property from the parties involved, and transform them into a question of formal law. This made Christie argue for the importance of solving conflicts by recourse to different forms of alternative dispute resolution (Christie, I977). It is largely in this same line of thought that the Danish sociologist of law Jørgen Dalberg-Larsen examined the development of law and the state from the Rechtsstat to the welfare state and beyond (Dalberg-Larsen, I984). While pointing to the limits of welfare state regulation, he argues for a form of regulation somewhat similar to what Gunther Teubner later called 'reflexive law', that is, a form of law where the parties actively take part in solving the conflict. In this line of thought, state institutions should merely provide the framework in which the parties should settle their disputes.

Many of these developments towards alternatives to both formal law and welfare state regulation are of course closely linked to critical theory and approaches developed at several universities in Scandinavia in the I970s. Particularly at Oslo University, a number of researchers associated with the sociology of law sought to merge socio-legal research and political engagement with what was labelled 'action research'. This was not only an attempt to solve sociology's dilemma between action and cognition, but also a very concrete way of providing aid to less resourceful persons who, regardless of the paroles of the welfare state, were in dire situations. One of the most celebrated action research projects in Scandinavia was the so-called 'Juss-Buss' project (the 'law bus' project), established by law students at University of Oslo in I97I. The project came to life as a reaction to a number of studies that had shown that the distribution of legal services between citizens was grossly unequal. In fact, although citizens with limited resources needed legal advice more than other groups in society, they were the group receiving the least legal counselling. Establishing legal aid clinics meant that it was possible to help this group of people while law students could work with the law in practice as a supplement to their more formal studies of law. A bus was bought from which they offered legal aid free of charge in poor neighbourhoods. The project also generated data for understanding citizens' legal needs and the reasons why some people did not seek legal advice (Hammerslev and Mathiesen, 2013). Several books and papers concerning citizens' legal needs and living conditions have been published based on data from the 
project (Juss-Buss and Rønning, 20II). Another example of action research was the establishment of the Norwegian association 'KROM' (Norsk forening for kriminalreform / Norwegian association for criminal reform), which consisted of inmates, former inmates and lawyers with the common goal of helping current and former prisoners advocate for better conditions and more generally raise awareness about their legal concerns (Mathiesen, 20II).

\subsection{From critical engagement to post-modern anxieties in a globalising world}

A number of new research directions emerged from the development of the discipline in the I 980 s and the I99os. In Denmark, particularly in Copenhagen, the sociology of law developed strongly in the direction of criminology. ${ }^{7}$ However, the development of the sociology of law as a discipline distinct from criminology received much less attention. The relatively few studies conducted in the sociology of law in the r980s and I990s generally had a theoretical focus, particularly concerning the concept of law. The sociology of law, it was argued, was a part of legal sciences and, therefore, the general audience was a legal one (Dalberg-Larsen, 2000a; Hydén, 2002b). The most renowned scholar in the field in Denmark, Jørgen Dalberg-Larsen, conducted inquiries into both the theoretical development of the sociology of law and its relevance for understanding the transformation of the state (Dalberg-Larsen, I984). He eventually took a more explicit Habermasian starting point for understanding law when he embarked on his studies of dispute resolution in the welfare state (see above). This was followed by a number of publications discussing the concept of law against the background of, for example, post-modernism, legal pragmatism and pluralism (Dalberg-Larsen, 200I, I998, 2000a, 2000b).

At around the same time, the Swedish scholar Håkan Hydén embarked on developing a specific theoretical framework about norms ('norm science') at the Sociology of Law Institute, Lund University, Sweden. Hydén's scholarship is a good illustration of the overall transformation of the discipline. While Hydén early on used a number of sociological theories in his studies of labour law, his later writings on norm science turned towards ideas of the sociology of law as an emancipatory science in line with other scholars of the period seeking to combine post-modern understandings with law and emancipation (notably Santos, 1995). With very few exceptions, norms and their role in social behaviour became the overarching analytical framework for a significant number of socio-legal dissertations and studies at Lund University, often dealing with issues closely related to the Swedish welfare state. These studies analysed the existence of different norms and their relationship and functions in different socio-legal areas. Norms were generally seen as latent practices, and legal norms in particular were of interest in this regard as they, if relatively powerful in relation to a set of contextual factors, can lead to social (and legal) action (Hydén, 2002a).

In Oslo in the I99os, Inger-Johanne Sand also contributed to these debates on the concept of law and post-modernity. Taking a starting point in systems theory (derived from German legal sociology, i.e. Luhmann and Teubner specifically) in combination with a post-modern focus on discourses, she has examined how public law and public institutions are capable of handling the complexities of late modern societies. Her focus has been on differentiated needs from users of public services and globalised markets and challenges, particularly as these needs develop with increasing regulation and dominance from the EU (Sand, 2008), technological developments and the specialisation

7 The move into criminology was taken by researchers such as Berl Kutchinsky (famously studying the liberalisation of pornography's effect on crime rates), Ulla Bondeson (studying the damaging effects of imprisonment and variations in the choice of sanction and sentencing tariffs), Annika Snare (studying a series of subjects related to victimology, women and crime, and restorative justice), Flemming Balvig (studying youth crime, violent crime and many other issues) and Anette Storgaard from Aarhus University (studying juvenile justice, drug treatment and many other issues). 
of law and professionals (Sand, I996). According to Sand, the welfare paradigm and political management can no longer simply be extended as it is in fact challenged by other discourses, such as the market discourse with its focus on efficiency. In recent years, Sand has increasingly focused on hybrid forms of law as solutions and reality in hyper-complex societies.

Forms of post-modernism and legal pluralism also became a focal point of the work of Hanne Petersen in Copenhagen during the same period. ${ }^{8}$ Petersen generally argues that law can no longer be abstracted to a coherent unit with equally valid legal sources. Instead, law must be seen as different subsystems with different legal sources and informal norms with variations in their validity, and which are hierarchised differently in the subsystems. This specific branch of legal pluralism, which was termed 'legal polycentricity' (Blume and Petersen, I993; Petersen and Zahle, I995), caused great debate in Scandinavia about the concept of law and legal methods. This research was not sociological in the classic sense, not least because it was not very empirical - at least when seen from a conventional social scientific perspective. What is striking about these studies is that they departed from the strong empirical and sociological focus of the pioneering generation. Their starting point, not unlike the later work of Sand and others, was more legal jurisprudential in some ways - in combination with a subscription to a post-modern research ethos. While Petersen returned to the field of the Danish pioneers of the sociology of law and found - in line with Bentzon - that law was practised and existed as many intertwined informal and formal norms, her approach was strikingly different (Petersen, 2006). Rather than being based on a social scientific research paradigm, she instead emphasised other approaches - often inspired by post-modern and more humanistic approaches - and examined questions concerning, for example, law and art or love. In contrast, Bentzon, who had now joined forces with Torben Agersnap, adopted a grounded-theory approach when she examined legal cultures in Third World countries (Bentzon, Hellum and Stewart, I998).

\section{The turn to social science: the new sociology of law in Denmark}

While current sociology of law in Scandinavia is in many ways indebted to the previous generation of studies and researchers, in Denmark it has taken a distinctly sociological turn, which in practice means that it often has more in common with the pioneers such as Aubert than with the immediately preceding generation on account of its clear empirical and institutional orientation. ${ }^{9}$ The sociological frameworks of inquiry, however, are different from the work of Aubert and his generation. The new scholarship obviously seeks to point forwards rather than backwards in its application and redevelopment of frameworks of inquiry derived from general sociology. In the following, we outline a number - but not all - of these studies in order to highlight general research trends in contemporary Danish sociology of law. We begin with studies of the legal profession, which, in contrast to earlier related research, have sought to rethink the evolution of the profession in a more global context. Second, we focus on more micro-sociological studies of practices around law and legal institutions. Last, we turn to studies related to law and crime that employ more structural sociological approaches.

8 Hanne Petersen has also been a pioneer in feminist studies of law and multiculturalism. In this outline we have left feminism out because it is a far larger movement than the sociology of law in Denmark and Scandinavia and cannot be fairly introduced as only part of the history of the sociology of law. For introductions, see Jørgensen (20II) and Schömer (20I3).

9 One exception to the trends we have outlined is, of course, Reza Banakar, who began his socio-legal career at Lund University, the Sociology of Law Department, before he went to work in the UK for many years, returning recently. His pioneering study on ethnic discrimination in Sweden pointed towards the contemporary current of sociology of law; see Banakar (I998). 


\subsection{The legal profession - globalisation and transformation}

The work of Margareta Bertilsson cited above opened up a rethinking of the rather strict relationship between the legal profession and the state which was featured centrally in inquiries into the legal profession up until that point. Basically, although the legal profession is very clearly losing out at the heart of the state administration - and in politics more generally (Pedersen, I972) - jurists are, as Bertilsson suggests, nevertheless gaining new markets. In other words, although the 'jurist state' is in steady decline on account of the loss of monopolies - implying that legal civil servants and judges in particular have had a relative loss of power and prestige - the profession more generally has nevertheless managed to remain not only highly attractive but also highly lucrative, at least for those in a big law firm practice. Bertilsson et al. did not explore the actual transformation taking place, but only hinted at this change at the core of the legal profession as going from public servants to entrepreneurs of the private market.

One of the first studies to analyse these crucial transformations in Scandinavia was conducted by Mikael Rask Madsen in the late I990s. Analysing the change in the practice of law from relatively small barristers' offices to the emergence of large law firms with clear inspiration from the large US and London city law firms, Madsen not only detailed the organisational implications of these changes but also how they effectively transformed the legal field at large by triggering the development of a new legal elite (Madsen, 2000). More specifically, this transformation first and foremost implied the importation of a hitherto unknown market factor into the practice of law in Denmark. This was visible in new competition between law firms and implied an approximation of the world of business and the world of legal practice. With this, the large firms helped kick off a process of differentiation in the legal field, which entailed the emergence of a set of increasingly differentiated segments of legal professionals. In this respect, the large law firms sought to establish themselves as a new dynamic legal business elite - although moulded on an older one of supreme court barristers - by introducing a new symbolic and professional resource of considerable economic value: being a large law firm lawyer. ${ }^{10}$ Madsen revisited the law firms ten years later to assess the evolution of the profession and its long-term impact on the legal field (Madsen, 2008). If the largest firm in 1998 employed I Io jurists, it had increased significantly by 2008 . Among the top-five law firms, the average growth was up to 200 per cent over ten years. This phenomenal growth rate had been achieved by intense merger activity, and as a consequence of the specific organisational structure of the large law firm (as theorised by Galanter and Palay, I991). Moreover, as the initial study predicted a decade earlier, these firms had increasingly developed into a distinct subfield of the legal field. They had in other words differentiated themselves even further vis-à-vis the profession at large, moving away from the classic politics of professionalism (Abel, I99I) and towards a new legal business culture (Boltanski and Chiapello, 2007; Sennett, 2006).

The sociological framework for this study was in part the expanding North American literature exploring and theorising the transformation of the practice of law. However, the most important sociological tools for conducting a systematic empirical study were derived from French sociology, and particularly the work of Pierre Bourdieu in terms of theoretical models (Bourdieu, I987, I99I, I980, I977; Bourdieu, Chamboredon and Passeron, I99I; Bourdieu and Wacquant, I992), and Yves Dezalay in terms of the specific object of study (Dezalay, I992; Dezalay and Garth, I996; Dezalay and Sugerman, 1995). The perhaps most important insight which can be derived from these studies is, on the one hand, the intra-professional struggles of the legal field and, on the other hand, how the legal field interfaces with a whole series of other social fields, including notably academia, the business world, the state and many others. This is crucial for understanding the

Io Comparable observations have also been made with regard to the practice of law in Norway; see Bahus and Ali (200I); Papendorf (2002). 
important difference between these frameworks of inquiry and those used in earlier sociology of law in Scandinavia, which relied on functionalism and, subsequently, systems theory for explaining law as norms - and typically not as practices. While functionalism is particularly suitable for explaining the microcosm of law in continuation with intra-legal debates, the Bourdieusian-inspired sociology of law profoundly challenges its ability to explain law in its larger societal interface (Dezalay and Madsen, 20I2; Hammerslev 2013).

Similar epistemological and theoretical reflections laid the foundation for Ole Hammerslev's empirical study of the evolution of the Danish legal profession in general and the judiciary specifically in the early 2000s (Hammerslev, 2003). Here Hammerslev finds that the Danish judiciary is increasingly differentiated. This is in particular the result of a rather well-concealed recruitment pattern which basically produces stratified access to the courts: the higher the court, the higher the social background of the recruits. The social consequence of this logic is straightforward. There is a real social cleavage between the provincial lower courts and the higher courts, most of them placed in the capital, Copenhagen. As such, according to Hammerslev, there is a growing social distinction between the levels of courts which, conversely, reinforces a convergence in social outlooks at each of the levels of courts. Moreover, in the later part of the twentieth century, the judicial elite became increasingly associated with the Ministry of Justice and its institutions as well as the prosecutor's office and the police, where they often received their initial training. This, together with identified patterns in their social backgrounds, Hammerslev argues, has real consequences for the way legal questions are viewed at each level of the court system. Put another way: social habitus potentially influences legal outlook.

Both Hammerslev and Madsen have in recent years turned their attention to how objectively similar processes of professional competition are at the heart of processes of global restructuring and regulation. Hammerslev, for his part, has particularly scrutinised how the law and legal institutions of the new Eastern Europe were built in continuous competition between different visions and missions for the interface of law, society and state (Hammerslev, 20II, 2007b). He shows particularly how the EU and the US are in fact competing over the definition of relevant expertise and ideas of the state. Madsen, examining the genesis and transformation of European human rights from World War II until the present, provides an account of how the symbolic force of law is manufactured in a complex interplay of legal agents, state agencies, courts and NGOs within a significant structural and geo-political transformation which made the emergence of an integrated Europe possible (Madsen, 2005, 2010). In his more recent work on the international judiciary (Madsen, 20II, 20I4), he explores international courts in the matrix of processes of global restructuring, particularly throughout the twentieth century, in combination with a detailed analysis of the interior socio-legal processes of the making of not only international law but also of the institution - legally, politically and socially - of international courts.

Recently, Jens Arnholtz has followed similar research patterns. In his work on the construction of the European Court of Justice's Laval ruling as a social, political and legal phenomenon, he also adopts a Bourdieusian approach. The Laval ruling has come to be a symbol of how the EU is challenging workers' rights, and as such it has been intensely debated in legal, political and scholarly circles. Based on extensive empirical research, Arnholtz exemplifies that the huge symbolic impact of the ruling was not caused just by the content of the ruling or its material consequences; rather, the political context, the build-up of the case and the political aftermath have played decisive roles in making this ruling stand out as a symbol of how the European Court of Justice encouraged social dumping and the downgrading of workers' rights (Arnholtz, 20I4).

\subsection{Legal institutions and their interlocutors}

It would be misleading to present Danish sociology of law as driven only by the Bourdieusianinspired sociology of the legal field, institutions and professions. Other, mainly French, theories 
are certainly also very present, including Michel Foucault and contemporary sociological pragmatists such as Luc Boltanski and Bruno Latour. German sociologist Niklas Luhmann has also had a following. In what follows we do not by any means attempt to provide an exhaustive outline of all studies conducted in the field of the sociology of law in Denmark, but rather emphasise those studies which we believe are representative of new directions in socio-legal research. We outline the work of a set of emerging sociologists of law who have all embarked on in-depth studies of key institutions of law, or the practices taking place in close vicinity to the institutions of law. While they have a commonality in their clear empirical orientation, they also differ significantly in both their theoretical and methodological approach.

Anthropologist Louise Victoria Johansen has in three closely related studies of Danish courtrooms focused on micro-sociological processes related to knowledge formation in and around the law. In these studies, she has analysed how legal decisions in the courtroom are dependent on very different kinds of knowledge that are often produced and processed during the early stages of cases. More specifically, non-legal actors (strictly speaking), such as psychologists and social workers, are co-creators of the facts that eventually form part of the defendant's case file. Theoretically inspired by Bruno Latour (Latour, 2002, I987), Johansen has used an Actor-Network (ANT) approach to explain the contingency of different forms of knowledge with the goal of challenging not what the law is - or is supposed to be - but to deconstruct the often taken-forgranted knowledge that is typically presented as 'facts' in the courtroom. In this regard, her work also intersects with the work of Mariana Valverde (Valverde, 2003), and more generally the anthropology and sociology of knowledge as it pertains to legal and quasi-legal knowledge, a field of inquiry which has boomed in recent years (for example, Jasanoff, I997; Riles, 2006).

In a first study using qualitative, anthropological methods such as interviews, participant observation and discourse analysis of case documents (Johansen and Stæhr, 2007), she demonstrated how difference matters, in particular difference with regard to belonging to certain social and ethnic groups, as well as gender more generally. Legal actors' knowledge of a case or a defendant is influenced by the ways in which different values and cultural perceptions of, for example, family ties and upbringing are communicated between the relevant actors, yet these gradations in communication and their potential impact pass largely unnoticed by most Danish legal actors, including judges. In a second study (Johansen, 20I2), Johansen used similar methods as well as multi-sited fieldwork over a prolonged period of time to examine how the Danish penal system responds to defendants' personal and social backgrounds, particularly in relation to how these are formulated and gathered in so-called pre-sentence reports. Basically, the main questions here are: What kinds of knowledge about the defendant are considered relevant by the legal actors? What actions can be taken on the basis of this type of knowledge and these knowledge processes? And, not least, what is left out and remains silent? A third ongoing study focuses on laypeople in criminal cases, more specifically jurors. The study follows thirty jurors over their appointed period of four years, and examines the ways in which they participate in the cases and deliberations during this time. The preliminary findings indicate that, although jurors are recruited to guarantee soundness and 'common sense' in legal deliberation, it seems that their arguments change over time and become increasingly 'juridified' in their interaction with the professional jurists. They basically undergo a situated learning process (Lave and Wenger, I99I) that gradually teaches them legal language and ways of thinking.

This relates to an earlier study by Rasmus Wandall, who examined how formal and informal norms and ideologies impact decisions to imprison in Danish courts (Wandall, 2008). Through observations, interviews and quantitative studies, he demonstrates how decision-making processes in Danish courts are on the one hand open to more than its formal legal framework, namely to informal norms and ideologies about the defendant's background, appearance in court, family network, etc., while the sentencing is on the other hand kept within the boundaries of law and 
legal validity. In contrast to the other studies outlined in this section, Wandall rethinks Niklas Luhmann's theory on law's operational closure as a productive tool to study the interaction between law and extra-legal effect on decision-making in court. As a result, he manages to capture the subtle interactions between law's manifest claim to validity and the latent contextual openness in everyday legal operations.

Recent work on mediation and restorative justice councils also explores micro-level processes in the shadow of the law. Lin Adrian examines so-called 'court-connected mediation' in Denmark with the goal of uncovering whether and to what extent court-connected mediation in practice forms the kind of alternative to regular legal proceedings and adjudication that it claims to (Adrian, 20I2). While mediation and various forms of alternatives to conventional legal dispute resolution were a political priority on the socio-legal studies' agenda in the I970s (Garth, 200I; Teubner, I983), Adrian goes further in her study and takes a distinct empirical approach. Adrian conducts a systematic empirical study of twenty court-connected mediations in cases filed in court, including interviews with the parties, and an archival study of forty-two mediated agreements. In her work on Danish restorative justice councils, Ida Asmussen deploys a Foucaultian framework, and particularly the notion of pastoral power (Asmussen, 2013). Using this framework in combination with qualitative interviews and observations, she examines Danish restorative justice councils and describes their proceedings as a modern variation of Christian absolution. Basically, during the restorative process, the perpetrator must perform a role characteristic of the ideal sinner, i.e. to show contrition, understanding for the injured party and a will to live a sinless life. On the other hand, the injured party performs a character which shows Christian charity, gives pardon and shows a genuine interest in the rehabilitation of the perpetrator. While both studies are clearly inscribed in a socio-legal tradition dating back to the I970s of scrutinising alternatives to judicialised dispute resolution, they are not primarily concerned with presenting a normative plea for alternatives to courts, but rather with using empirical social-scientific methods to present a critical study of these forms of dispute resolution in the shadow of formal legal institutions.

\subsection{Prisons and policing from structural sociological perspective}

As suggested above, criminology has been a big part of Danish sociology of law, particularly at the University of Copenhagen. It could be argued - as most of the researchers involved probably would - that the research about crime and society conducted since the late r 960 s has indeed been criminology and not the sociology of law. The distinction is, of course, in some regards difficult to make, but there is nevertheless little doubt that two recent empirical studies in the area are indeed works of the sociology of law. These works focus on, respectively, the legal consciousness of re-offenders in relation to their imprisonment and re-entry into society, and the genesis and transformation of the Danish police. Other studies could also have been included here to illustrate the same transformation in scholarship, notably the analysis conducted by Christian Borch in Copenhagen, drawing on Niklas Luhmann and Michel Foucault in his exploration of the relationship between power and crime (Borch, 2005). ${ }^{\text {II }}$

The work of Annette Olesen shares Johansen's above-cited work's interest in the ways in which knowledge of law - and particularly knowledge of how to manipulate law - is of key importance. Her study, however, takes a more structural sociological orientation, thus differing from Johansen's anthropological starting point. Firmly rooted in Bourdieusian reflexive sociology (of law) while using contemporary theories of legal consciousness (Ewick and Silbey, I998; Merry, I990; Sarat, I990), her research relates not to court proceedings as such but rather to what in some cases

I I Another example of this is Thomas Ugelvik's work at Oslo University in Norway on prison life (Ugelvik, 20I I) and Linda Kjær Minke's work at the University of Southern Denmark on prison life in Denmark (Minke, 20I2). 
follows: prison. Or, to be even more precise, what follows after prison when inmates seek to re-establish their lives. While there is a growing amount of research into the prison environment (for example, Thomas Ugelvik's and Linda Kjær Minke's studies: see note II), much less is known about the legal barriers that re-offenders face in their re-entry into society. In her thesis and subsequent book Free'd n' Fee'd [our translation], Olesen explores the legal consciousness of reoffenders with regard to their imprisonment and re-entry into society (Olesen, 2013). She furthermore examines the habitus of re-offenders: the strategies of action that the re-offenders develop as a response to the ways in which they experience the legal regulation of their possible living conditions. To conduct this study, she gathered qualitative data throughout Denmark over a period of two and a half years, including repeat interviews with forty-one male re-offenders.

The core argument of the book concerns the discrepancy between the intended goal of legislation and how it is experienced and practised by re-offenders. Olesen demonstrates how a set of other factors limit the effect of the laws put into place to re-insert former offenders into society. Generally, the experiences of the legal barriers concerning re-entry into society affect the lawabiding ex-prisoners negatively. Strategies of action cause an 'unofficial economy and occupation', an 'alternative safety net', 'alternative ownership' and 'fictive addresses' are used by some exprisoners, who continue a criminal career in order to compensate for the legal barriers they experience during their re-entry process. Contrary to more law-abiding ex-prisoners, ex-prisoners who continue their criminal career and evade the registration of the authorities to only a minor degree, experience the legal barriers of e.g. their criminal record and debt of legal cost to the state. In particular, the book argues that indebtedness is a major contributing factor in ex-prisoners relapsing into crime and a direct criminal risk factor in this regard.

Another emerging Danish socio-legal scholar, Mikkel Jarle Christensen, has analysed another side of the same issue, namely the evolution of policing in Denmark from its genesis to its transformation by new public management, and what sociologist Luc Boltanski has termed the 'projective approach' to work (Boltanski and Chiapello, 2007). In his book From the Eternal Police to the Project Police [our translation] (Christensen, 20I2), he traces this evolution of the police and policing using an unusual constellation of theoretical frameworks, namely the somewhat opposed theories of Pierre Bourdieu and Luc Boltanski. Yet, using this combined structural and pragmatist analytical framework, he manages to study not only how the ideology of policing has changed over time, but also how the battles between different actors in and outside the police were crucial to the change in ideology. In other words, he presents a study of both the transformations in ideology and the precise structural conditions that made those changes possible. The empirical material used for this historical sociological analysis takes its point of departure from the various battles surrounding a set of large-scale reforms of the Danish police, including the debates on the actual reform texts and their preparatory works, as well as archival material gathered from the host of actors involved in this process. In addition, Christensen conducted interviews to supplement the archival material from the most recent periods of time he studied.

Focusing on the sequential reforms of the police, Christensen demonstrates how such reform processes were key occasions for the importation, definition and legitimisation of new normative ideals of policing. The study traces the structuration of the police by a focus on the relative ruptures caused by each of these reforms. Drawing on Boltanski's seminal analysis of the transformation of the spirit of capitalism, Christensen labels the most recent incarnation of the Danish police 'the projective police'. This came about partly as an explicit opposition to the industrial police, which was long focused on measurability, and partly as a result of the transnational importation of new ideas and ideologies of policing, which promoted new criteria such as flexibility, creativity and network-based solutions. Interestingly, this form of projective policing was championed mainly by external actors, in particular the consultants hired to assist with the reform process, but was eventually implemented largely due to the interests of an 
internationalist elite of police officers who had a long history of taking part in transnational police work, typically concerning organised crime. On account of how it views what is at first glance a highly national process of police reform in an international context, Christensen's study links with the studies on the current international transformations of the legal profession outlined above (see also Christensen, forthcoming).

\section{Conclusion: from socio-legal studies to the new Danish sociology of law}

We have structured these two last parts of this paper on the new Danish scholarship in the area of the sociology of law around a set of studies that are likely to have, on account of them being published in Danish, slipped under the radar of the international community of sociologists of law. For this reason, we have opted to put much less emphasis on studies that have already appeared in English-speaking journals or which have been published in other major languages. Moreover, we have chosen not to discuss a set of research areas that, despite having been central to socio-legal scholarship, in practice involve far larger domains of research. These include feminist studies and the recent wave of studies about multiculturalism. Even within our more limited sample we do not claim to provide a full list of recent and relevant works, ${ }^{\mathrm{I}}$ but rather a set of studies that are illustrative of a general change within the sociology of law regarding the emergence of a new sociologically driven sociology of law in Denmark. Although our approach has its limitations, we can nevertheless generally conclude that there is a discernable transformation going on in the scholarship - one that might be best described as the return of sociology in Danish sociology of law. This question of the role of sociology in the sociology of law is in practice evocative of broader changes in both scientific interest and outlook, and the condition under which the sociology of law is produced. Accordingly, we will conclude the paper by briefly exploring the causes and consequences of these changes.

There is a perceptible difference between the applied - often action-oriented - scientific approach that took hold in the I970s and the outlined contemporary Danish scholarship, which in many cases is more oriented towards basic science problems and general sociology. Because of the fairly weak position the sociology of law long held in most universities combined with the political climate of the time, the need to both write to a legal audience and supply radical ideas was hardly conducive to the kind of studies we encounter now, which conversely have benefited from more independent funding for empirical research (Holtermann et al., 2013b, pp. 99-100). For a long time, a key point of dispute within the sociology of law was how it should balance orientations towards law on the one hand and sociology on the other. A solution was in many cases initially found in so-called 'legal sociology' (or socio-legal studies), which was sufficiently oriented towards law to legitimise research practices, while the research constituting the contemporary sociological turn appears to more bluntly orient itself towards sociology in terms of research practice. This turn, however, should not be taken to disregard the fact that it still views law as a key audience and institutional home for conducting this branch of research.

Another striking feature of contemporary scholarship is that it is much more globally oriented than earlier scholars, who were very often deeply involved in Scandinavian exchanges. There is little doubt that a consequence of the current development of the discipline in Denmark is that the sociology of law will become increasingly less regionalised - and more globalised. One could argue that the current developments in Denmark are shaping the research area so that it actually resembles French more than Swedish sociology of law (Israël, 2013). This raises the question of how Danish or Scandinavian the outlined new scholarship can be said to be. Moreover, although the works have for various reasons been published in Danish, the analyses presented are for

I 2 Other relevant contemporary authors are, for example, Frederik Thuesen and Bettina Lemann Kristiansen (see Storgaard and Lemann Kristiansen, 20I0; Thuesen, 2008). 
the most part speaking to an international audience. These obvious international features notwithstanding, there is probably still a distinct local dimension to most of this scholarship. The reason for this is the same as that which made the work of, for example, Vilhelm Aubert distinct from his American contemporaries: the relative sociological particularity of Scandinavia. Thus, regardless of the massive mobilisation of the heaviest artillery of international sociology, there is still a required adaptation and innovation at the level of both theory and empirical analysis if the law and society of this relatively small, for some obscure, region of the world is to be made intelligible.

\section{References}

ABeL, Richard L. (I99I) American Lawyers. Oxford: Oxford University Press.

ADRIAN, Lin (20I 2) Mellem retssag og rundbordssamtale: Retsmeegling i teori og praksis. Copenhagen: Jurist og Økonomforbundets Forlag.

Agersnap, Torben (2000) 'Theodor Geiger: Pioneer of Sociology in Denmark', Acta Sociologica 43: 325-330.

ARnholtz, Jens (2014) A 'Legal Revolution' in the European Field of Posting? Narratives of Uncertainty, Politics and Extraordinary Events. Unpublished PhD thesis, Department of Sociology, University of Copenhagen.

ASMUSSEn, Ida (2013) Fra retsstat til omsorgsstat - Om syndsforladelse i konfliktråd. Unpublished PhD

Thesis, Faculty of Law, University of Copenhagen.

AUBERT, Vilhelm (I976) 'The Changing Role of Law and Lawyers in Nineteenth- and Twentieth-

Century Norwegian Society', in Donald Niel MacCormick (ed.), Lawyers in Their Social Setting.

Edinburgh: W. Green \& Son, I-I7.

AUBERT, Vilhelm (I982) Rettssosiologi. Oslo: Universitetsforlaget.

AUBERT, Vilhelm, ECKHOFF, Torstein and sverI, Knut (I952) En lov i søkelyset: Sosialpsykologisk undersøkelse. Oslo: Universitetsforlaget.

BAHUs, Marianne Klungland and ALI, Rehana Inayat (200I) Advokatstanden i Norge: En rettssosiologisk studie av advokatene i Norge, med vekt på faglig og sosial bakgrunn, yrkesvalg, arbeidserfaring, inntekt og likestillingsproblematikk. Oslo: Faculty of Law, Oslo University.

BanaKar, Reza (I998) Doorkeepers of the Law: A Socio-Legal Study of Ethnic Discrimination in Sweden. Aldershot: Dartmouth/Ashgate.

Bentzon, Agnete Weis, Hellum, Anne and stewart, Julie (I998) Pursuing Grounded Theory in Law: SouthNorth Experiences in Developing Women's Law. Harare: Mond Books.

BERTILSSON, Margareta (I996) 'An Ancient Science? On the Continuing Relevance of Law', in Ragnar Björk and Karl Molin (eds), Societies Made up of History. Edsbruk: Akademitryck, I69-193. BertiLsson, Margareta (1989) 'The Legal Profession and Law in the Welfare State', in Aulis Aarnio and Kaarlo Tuori (eds), Law, Morality, and Discursive Rationality. Helsinki, 9-3 I.

Bertilsson, Margareta (1999) 'On the Role of the Professions and Professional Knowledge in Global Development', in Therborn Göran and Lise-Lotte Wallenius (eds), 99:5. Stockholm, 73-100. BERTILSSON, Margareta (ed.) (I995) Rätten i förvandling. Jurister mellan stat och marknad. Stockholm: Nerenius \& Santerus Förlag. Blegvad, Britt-Mari (ed.) (I966) Contributions to the Sociology of Law. Copenhagen: Munksgaard. BLEGVAD, Britt-Mari (I973) Juristernes rolle i samfundet. Copenhagen: Nyt fra Samfundsvidenskaberne. BLEGVAD, Britt-Mari (I975) 'De juridiske eksperter - Tre Professioner', in Hans Gullestrup, Tore Jacob

Hegland and Bjarne Herskin (eds), Eksperterne og magten: Professionelles rolle i organisationer og samfund. København: Nyt Nordisk Forlag Arnold Busck, 224-255.

BLUME, Peter (2013) 'Sociologiens fornyede indtogsmarch', Retfard-Nordic Journal of Law and Justice 4: 93-97.

Blume, Peter and Petersen, Hanne (1993) Retlig polycentri. København: Akademisk Forlag. 
Boltanski, Luc and Chiapello, Eve (2007) The New Spirit of Capitalism. New York: Verso. BORCH, Christian (2005) Kriminalitet og magt. Copenhagen: Kritisk Revy. BouRdieu, Pierre (1977) Outline of a Theory of Practice. Cambridge: Cambridge University Press. Bourdieu, Pierre (1980) Le Sens Pratique. Paris: Minuit.

BouRdieu, Pierre (1987) 'The Force of Law: Toward a Sociology of the Juridical Field', Hastings Law Journal 38: 805-853.

BOURDieu, Pierre (I99I) Language and Symbolic Power. Cambridge, MA: Harvard University Press. Bourdieu, Pierre, chamboredon, Jean-Claude and passeron, Jean-Claude (I99I) The Craft of Sociology: Epistemological Preliminaries. Berlin: Walter de Gruyter.

Bourdieu, Pierre and WaCQuant, Loïc (I992) An Invitation to Reflexive Sociology. Chicago: University of Chicago Press.

CHRistensen, Mikkel Jarle (2012) Fra det evige politi til projektpolitiet: En kamp om position og ideologi. Copenhagen: Jurist og $\emptyset$ konomforbundets Forlag.

CHristensen, Mikkel Jarle (forthcoming) 'Between the National and the International: How International Prosecution Is Limited by National Judicial Fields: The Case of Denmark', International Political Sociology.

CHRISTIE, Nils (I977) 'Konflikt som eiendom', Tidsskrift for retsvœesen: I I3-I32.

DALBERG-LARSEN, Jørgen (I984) Retsstaten, velferdsstaten og hvad så? København: Akademisk Forlag. DALBERG-LARSEN, Jørgen (I998) Ret, tekst og kontekst. København: Jurist- og Økonomforbundets Forlag. DALBERG-LARSEN, Jørgen (2000a) 'Sociology of Law from a Legal Point of View', Retford-Nordic Journal of Law and Justice 23: $7 \mathrm{I}-80$.

DALberG-LARSEN, Jørgen (2000b) The Unity of Law: An Illusion? On Legal Pluralism in Theory and Practice. Berlin: Galda und Wilch Verlag.

DALbERG-LARSEn, Jørgen (200I) Pragmatisk retsteori. Copenhagen: Jurist- og Økonomforbundets Forlag. DeZAlay, Yves (1992) Marchands De Droit; La Restructuration De L'ordre Juridique International Par Les Multinationals Du Droit. Paris: Fayard.

DEZAlay, Yves and GaRTH, Bryant G. (1996) Dealing in Virtue: International Commercial Arbitration and the Construction of a Transnational Legal Order. Chicago: University of Chicago Press.

DeZalay, Yves and madsen, Mikael R. (2012) 'The Force of Law and Lawyers: Pierre Bourdieu and the Reflexive Sociology of Law', Annual Review of Law and Social Science 8: 433-452.

dezalay, Yves and sugerman, David (1995) Professional Competition and Professional Power: Lawyers, Accountants and the Social Construction of Markets. London: Routledge.

ECKHOFF, Torstein (I968) 'Sociology of Law in Scandinavia', in R. Treves and J. F. Glastra Van Loon (eds), Norms and Actions: National Reports on Sociology of Law. The Hague: Martinus Nijhoff, 2 I-50. EWICK, Patricia and silbey, Susan S. (I998) The Common Place of Law: Stories from Everyday Life. Chicago:

University of Chicago Press.

FERRARI, Vincenzo (ed.) (I990) Developing Sociology of Law. Milano: Dott. A Giuffre Editore.

Galanter, Mark and Palay, Thomas (I99I) Tournament of Lawyers: The Transformation of the Big Law Firm. Chicago: University of Chicago Press.

GARTH, Bryant G. (200I) 'Tilting the Justice System: From ADR as Idealistic Movement to a Segmented

Market in Dispute Resolution', Georgia State University Law Review I8: 927-953.

GeIGER, Theodor (I946) 'Svar til Professor Alf Ross', Juristen: 309-324.

GEIGER, Theodor (I947) Vorstudien Zu Einer Soziologie Des Rechts. Aarhus: Acta Jutlandica.

goldschmidt, Verner, lindegaard, Per and Bentzon, Agnete Weis (I950) Betankning afgivet af Den Juridiske Ekspedition til Grønland I948-1949. Copenhagen.

HABERMAS, Jürgen (1987) Theory of Communicative Action: A Critique of Functionalist Reason. Cambridge: Polity Press.

HAMmersLev, Ole (2003) Danish Judges in the 2oth Century: A Socio-Legal Study. Copenhagen: DJ $\emptyset \mathrm{F}$ Publishing. 
hammerslev, Ole (2007a) 'Law and Society Activities in Scandinavia', in David S. Clark (ed.), Encyclopedia of Law and Society: American and Global Perspective. Thousand Oaks: Sage, I $343-\mathrm{I} 344$.

HAMmERSLEv, Ole (2007b) 'Reform Strategies around the Bulgarian Judicial Branch: Social Struggles Converted into Struggles about Court Reforms', in Ramona Coman and Jean-Michel De Waele (eds), Judicial Reforms in Central and Eastern Europe. Brugge: Vanden Broele, I35-I55.

Hammerslev, Ole (2010) 'Convergence and Conflict Perspectives in Scandinavian Studies of the Legal Profession', International Journal of the Legal Profession I7: I35-I 52.

HammersLev, Ole (20I I) 'The European Union and the United States in Eastern Europe: Two Ways of Exporting Law, Expertise and State Power', in Yves Dezalay and Bryant Garth (eds), Lawyers and the Rule of Law in an Era of Globalization. London: Routledge, I34-I55.

Hammerslev, Ole (2013) 'Studies of the Legal Profession', in Reza Banakar and Max Travers (eds), Law and Social Theory. Oxford: Hart Publishing, 325-340.

hammerslev, Ole and mathiesen, Thomas (2013) 'Marxistisk retssociologi', in Ole Hammerslev and Mikael Rask Madsen (eds), Klassisk og moderne retssociologi: Centrale temaer og tekster. København: Hans Reitzels Forlag, I8I-I98.

HOLTERMAnn, Jakob v. H. (20I3) 'Introduktion', in Alf Ross (ed.), Om ret og retfardighed: En indførelse i den analytiske retsfilosofi. Copenhagen: Hans Reitzels Forlag, 9-42.

holtermann, Jakob v. H., Christensen, Mikkel Jarle and madsen, Mikael R. (2013a) 'Kan retsvidenskaben være empirisk? Om aktualiteten af Alf Ross' empiriske vending i retsfilosofien', Retferd - Nordic Journal of Law and Justice 2: 3-22.

holtermann, Jakob v. H., Christensen, Mikkel Jarle and madsen, Mikael R. (20I3b) 'Replik til en dogmatiker', Retfard-Nordic Journal of Law and Justice I43: 98-102.

HYDÉN, Håkan (2002a) Normvetenskap. Lund: Lund University.

HYDÉN, Håkan (2002b) Rättssociologi Som Rättsvetenskap. Lund: Studentlitteratur.

HYDÉN, Håkan (2013) 'Klassisk nordisk retssociologi', in Ole Hammerslev and Mikael R. Madsen (eds),

Retssociologi: Klassiske og moderne perspektiver. København: Hans Reitzels Forlag, IOI-I I 9.

ISRAËL, Liora (2013) 'Legalise It! The Rising Place of Law in French Sociology', International Journal of Law in Context 9: 262-278.

JASANOFF, Sheila (I997) Science at the Bar: Law, Science, and Technology in America. Cambridge, MA: Harvard University Press.

JOHANSEN, Louise Victoria (2012) Livshistorier i straffesagen. Vidensprocesser om sigtedes person. Unpublished PhD thesis, Faculty of Law, University of Copenhagen.

JOHANSEn, Louise Victoria and STÆHR, Mette Høgh (2007) Lige for loven: En pilotundersøgelse af behandlingen af etniske minoriteter i straffesager (Research Report). Copenhagen: International Commission of Jurists.

JøRGENSEn, Stine (20II) 'Feministisk retsteori', in Ole Hammerslev and Henrik Palmer Olsen (eds), Retsfilosofi-Centrale tekster og temaer. Copenhagen: Hans Reitzels Forlag, 665-683.

Juss-Buss and RøNNING, Olaf Halvorsen (eds) (20I I) Med loven mot makta: Juss-Buss førti år. Oslo: Novus Forlag.

LATour, Bruno (1987) Science in Action: How to Follow Scientists and Engineers through Society. Cambridge, MA: Harvard University Press.

Latour, Bruno (2002) La Fabrique Du Droit: Une Ethnographie Du Conseil D'état. Paris: La Découverte. LAVE, Jean and WEnger, Etienne (I99I) Situated Learning, Legitimate Peripheral Participation. Cambridge: Cambridge University Press.

MADSEN, Mikael Rask (2000) 'Fra sagførerkontorer til store advokatfirmaer: En retssociologisk analyse af ændringerne af den danske advokatbranche', Juristen 3: I27-I4I.

madsen, Mikael Rask (2005) L'emergence D'un Champ Des Droits De L'homme Dans Les Pays Européens: Enjeux Professionnels Et Stratégies D'etat Au Carrefour Du Droit Et De La Politique (France, Grande- 
Bretagne Et Pays Scandinaves, I945-2000). Unpublished PhD thesis, l'École des hautes études en sciences sociales, Paris.

MADSEN, Mikael Rask (2008) 'Return to the Copenhagen "Magic Circle": First Elements of a Longitudinal Study of Large Law Firms in Denmark', Scandinavian Studies in Law 53: 303-3 I 9. MADSEn, Mikael Rask (2010) La Genèse De L'europe Des Droits De L'homme: Enjeux Juridiques Et Stratégies D'etat (France, Grande-Bretagne Et Pays Scandinaves, 1945-1970). Strasbourg: Presses universitaires de Strasbourg.

MADSEn, Mikael Rask (20I I) 'The Protracted Institutionalisation of the Strasbourg Court: From Legal Diplomacy to Integrationist Jurisprudence', in Mikael Rask Madsen and Jonas Christoffersen (eds), The European Court of Human Rights between Law and Politics. Oxford: Oxford University Press, 43-60.

MADSEN, Mikael Rask (20I4) 'Sociological Approaches to International Courts', in Karen Alter, Cesare P. R. Romano and Yuval Shany (eds), Oxford University Press Handbook of International Adjudication. Oxford: Oxford University Press, 388-4I2.

madsen, Mikael Rask and olsen, Henrik Palmer (20II) "Retsopgøret efter Ross": Retlig viden og Skandinavisk neo-Realisme', in Per Andersen, Pia Letto-Vanamo and Kjell A. Modeer (eds), Law, History and Culture: Festschrift to Ditlev Tamm. Copenhagen: DJ $\varnothing$ F, 575-586.

MATHIESEn, Thomas (I989) Skjellig grunn til mistanke? En studie av Forhørsretten. Oslo: Pax. MATHIESEN, Thomas (20I I) Kritisk sosiologi-En invitasjon. Oslo: Novus Forlag. MERRY, Sally Engle (1990) Getting Justice and Getting Even: Legal Consciousness among Working-Class Americans (Language and Legal Discourse). Chicago: University of Chicago Press. MINKE, Linda Kjær (20I2) Feengslets indre liv. Copenhagen: Jurist- og Økonomforbundets Forlag. olESEN, Annette (2013) Løsladt og goeldsat. Copenhagen: Jurist og Økonomforbundets Forlag. PAPENDORF, Knut-Erich (2002) Advokatens århundre? Globaliseringen og dens følger for advokatmarkedet. Oslo: Unipub Forlag Rapportserie, University of Oslo.

PEDERSEN, Mogens N. (1972) 'Lawyers in Politics: The Danish Folketing and United States Legislatures', in Samuel C. Patterson and John C. Wahlke (eds), Comparative Legislative Behaviour: Frontiers of Research. New York: Wiley-Interscience, 25-63.

PETERSEN, Hanne (2006) Retspluralisme i praksis - Grønlandske inspirationer. Copenhagen: Jurist- og $\emptyset$ konomforbundets Forlag.

petersen, Hanne and zahle, Henrik (1995) Legal Polycentricity: Consequences of Pluralism in Law. Aldershot: Ashgate.

RILES, Annelise (2006) 'Anthropology, Human Rights, and Legal Knowledge: Culture in the Iron Cage', American Anthropologist 108: 52-65.

ROSs, Alf (I950) 'Om begrebet 'Gældende ret' hos Theodor Geiger', Tidsskrift for Rettsvitenskap 63: 242-272. Ross, Alf (I 1966$)$ Om ret og retferdighed: En indførelse i den analytiske retsfilosofi. København: Nyt nordisk forlag Arnold Busck.

SAND, Inger-Johanne (I996) Styring av kompleksitet: Rettslige former for statlig rammestyring og desentralisert statsforvaltning. Bergen-Sandviken: Fakbokforlaget.

SAND, Inger-Johanne (2008) '(Re)Constructing the Boundaries of the Market: EU Law and Institutions Analysed through the Lens of Discontinuity', in Hanne Petersen, Anne Lise Kjær, Helle Krunke and Mikael Rask Madsen (eds), Paradoxes of European Legal Integration. Aldershot: Ashgate, 89-I Io. SAntos, Boaventura de Sousa (I995) Toward a New Common Sense: Law, Science and Politics in the Paradigmatic Transition. London: Routledge.

Sarat, Austin (I990) 'The Law Is All Over: Power, Resistance, and the Legal Consciousness of the Welfare Poor', Yale Journal of Law and the Humanities 2: 343-379.

schömer, Eva (2013) 'Feministiske retsteorier og retssociologi', in Ole Hammerslev and Mikael Rask Madsen (eds), Retssociologi: Klassiske og moderne perspektiver. Copenhagen: Hans Reitzels Forlag, 605-629. 
SEnNeTt, Richard (2006) The Culture of the New Capitalism. New Haven: Yale University Press. storgaArd, Anette and kristiansen, Bettina Lemann (2010) Nordisk Retssociologi: Status-Aktuelle Udfordringer - Visioner. Copenhagen: Jurist og Økonomforbundets forlag. TEUBNER, Gunther (I 983) 'Substantive and Reflexive Elements in Modern Law', Law and Society Review 239-285.

THUESEn, Frederik (2008) Menneskerettigheder oog solidaritet: Et studium med fokus på arbejdsmarkedet. Unpublished PhD thesis, Department of Sociology, University of Copenhagen.

UgelviK, Thomas (20II) Fangenes Friheter: Makt Og Motstand I Et Norsk Fengsel. Oslo:

Universitetsforlaget.

VAlVERDE, Mariana (2003) Law's Dream of a Common Knowledge. Princeton: Princeton University Press. wandall, Rasmus (2008) Decisions to Imprison: Court Decision-Making Inside and Outside the Law. Aldershot: Ashgate. 